Michnowicz, Jim. 2008. "Final nasal variation in Merida, Yucatan".

Spanish in Context 5.2. 278-303.

This version may differ slightly. Please cite the published version.

\title{
Final nasal variation in Merida, Yucatan
}

\author{
Jim Michnowicz
}

This article investigates the linguistic and social constraints on final nasal variation in Yucatan Spanish (YS), based on data collected in Merida, Yucatan. Absolute final nasals in YS may surface variably as: [n], [n], ø or [m] (e.g. pan $\rightarrow$ [pám], 'bread'). The results reveal a distribution of final nasal realization unique to YS, as well as detail its patterning throughout the community. Unlike some previous findings, the data under investigation here demonstrate [n] to be the preferred nasal variant, accounting for $60 \%$ of tokens. Regional variant [m] accounts for $25 \%$, while [n] and $\varnothing$ were infrequent variants, arising $8 \%$ and $5 \%$ of the time, respectively. Standard [n] occurs mostly among older speakers and Spanish monolinguals. Bilabial $[\mathrm{m}]$, however, is a recent innovation, led by younger speakers, women, and Mayan-Spanish bilinguals. The realization [m] may serve as a marker of regional identity for some speakers. For others, though, this variant is becoming a linguistic stereotype, as suggested by qualitative data from speaker comments and instances of $[\mathrm{m}]$ in the popular culture, including on internet websites.

Keywords: sociolinguistics, dialectology, Yucatan, nasals

\section{Introduction}

Yucatan Spanish (YS) is a regional dialect often stigmatized or ridiculed in other areas of Mexico, due primarily to both segmental and suprasegmental features. Distinctive features of YS mentioned in the literature include intonation; a preference for stop realizations of / b d g/ where other varieties would use approximant $[\beta \delta \gamma$ ], as in ['be.bo] for standard ['be. $\beta o$ ] 'bebo'; the aspiration of the voiceless stops / p t k/ as [ $\mathrm{p}^{\mathrm{h}} \mathrm{t}^{\mathrm{h}} \mathrm{k}^{\mathrm{h}}$ ], as in [' $\mathrm{k}^{\mathrm{h}} \mathrm{a} . \mathrm{sa}$ ] for standard ['ka.sa] 'kasa'; the maintenance of hiatus across word boundaries via the insertion of a glottal stop, as in ['o.t/o.'?a. nos] for standard ['o.tso'a.nos] 'ocho años', and; the feature studied here, the variable realization of final nasal consonants, (including the existence of a regional pronunciation found only rarely outside of Yucatan) as in ['bjem] for standard ['bjen] 'bien' (Lope Blanch 1987; Yager 1982; Michnowicz 2006b, and others). Al- 
though these non-standard features readily identify a speaker of YS within Mexico, in Yucatan, regional forms compete for prestige with national standards, and many speakers have a positive view of the dialect (Michnowicz 2006b). The local prestige given to YS by some speakers is a recent occurrence that has yet to receive much attention in the literature. This study, therefore, seeks to examine the tension between national and regional standards vis-à-vis linguistic and extra-linguistic (i.e. social) constraints on a regional feature, the realization of coda nasal consonants. Previous studies (Lope Blanch 1987; Yager 1982, 1989; García Fajardo 1984; Pfeiler 1992; Michnowicz 2006a, 2006b) have reported four possible nasal variants in YS: standard alveolar [n], velar [n], deletion of the consonant (ø) and a regional form [m] (Lope Blanch 1987; Yager 1982, 1989; Michnowicz 2006b). This variable is interesting from a purely phonological standpoint, as current theories of markedness do not predict a change from alveolar [n] to labial [m], especially in coda position (see Hume 2003 for a summary). From a sociolinguistic standpoint, Yucatan Spanish $[\mathrm{m}]$ is of interest due to the fact that it is the only regional variant that is not rapidly undergoing standardization (Michnowicz 2006b). Unlike the other regional variants mentioned above which have undergone a significant drop in frequency among younger yucatecos, $[\mathrm{m}]$ is increasing in frequency for some speakers of Yucatan Spanish. The present study was designed to determine what linguistic and social factors, if any, favor the use of one nasal variant over another via quantitative and qualitative sociolinguistic analysis. The rest of the paper is organized as follows: section 2 presents a sociolinguistic background of Yucatan, with particular emphasis on socio-historical factors that have impacted the development of YS as a variety of Spanish different from those of the rest of Mexico. section 3 reviews previous studies in the literature on YS final nasals, demonstrating the need for a quantitative study of this phenomenon. In section 4 , I outline the methodology used in the study. section 5 details the results of the multivariate statistical analyses (VARBRUL) to determine the linguistic factors influencing the realization of final nasals. section 6 presents the results of the analyses for social factors for each of the nasal variants. In sections 7 and 8, I discuss the results of the analyses on final nasal use, as well as provide possible explanations for the observed pattern. I also present qualitative evidence that the attitude towards the regional $[\mathrm{m}]$ may be undergoing change among some speakers. Finally, section 9 presents conclusions and areas for future research.

\section{Sociolinguistic background of Yucatan}

Yucatan has experienced a confluence of social and historical factors which have aided in distinguishing the regional dialect from other Mexican varieties. First, 
YS developed in contact with a widespread indigenous language, Yucatec Mayan. The contact between Spanish and Mayan continues to the present day, and as of the 2005 Mexican census, 33.5\% of the population reports speaking an indigenous language (i.e. Yucatec Mayan) (INEGI 2005). So, while one-third of the population still speaks Mayan presently, Mayan was much more widely spoken in the past, with much higher rates of bilingualism in previous decades (Lope Blanch 1987; Pfeiler 1992; INEGI). Yucatec Mayan is the second most widely spoken indigenous language in Mexico, after Nahuatl (Gordon 2005). Unlike other areas of Mexico, where indigenous languages exist in small pockets of often non mutually-comprehensible varieties, Yucatec Mayan covers the single largest block of territory, being spoken throughout the entire Yucatan peninsula (see Lope Blanch 1987: 9)

Lipski (1994: 51-55) demonstrates the importance of viewing colonial demographics in order to understand the genesis of a particular dialect. In the case of YS, colonial population records demonstrate the intensity of language contact throughout post-colonial history. Yucatan was an isolated region from the time of the conquest, and throughout the colonial period the peninsula received relatively little European or African immigration compared to the rest of Mexico (Weber 1980: 173). Throughout most of history since the conquest, the major Spanishspeaking cities of the peninsula (Merida, Valladolid and Campeche) existed as 'islands' of Spanish completely surrounded by the Mayan-speaking majority in the countryside (Mosely 1980: 86; cf. Lipski 1994: 80-81). Colonial records indicate that the native Spanish-speakers never constituted a large percentage of the peninsula's total residents. For example, shortly after the conquest of Yucatan, the population consisted of approximately 2000 Spaniards, 300 Africans, and 200,000 Maya (Mosely 1980: 102). At that time, Spanish-speakers made up only $1 \%$ of the total population of Yucatan. Although the Spanish-speaking population of course grew substantially during later centuries, they never constituted a majority during the colonial period, accounting for 10\% of the population in 1700 (Mosely 1980: 102), and climbing to $40 \%$ by 1794 (Mosely 1980: 104). Even in the 1970's, monolingual Spanish-speakers did not make up more than one half of the population of Yucatan (45\%) (Lope Blanch 1987: 9). Also important to the contact between Mayan and Spanish is that, unlike in other parts of Mexico, only one indigenous language is spoken throughout the peninsula, which some researchers have cited as an important factor in the possible existence of wide-ranging language contact phenomena in Yucatan (see Lope Blanch 1987: 9). In Yucatan, then, the process of conquest and subsequent Hispanicization was never completed to the same degree found in many other areas of Latin America, as attested by persistence of large numbers of Mayan-speakers to the present day. Barrera Vasquez (1937: 9) summarized the possible linguistic effect of a Mayan-speaking majority throughout most of the history of Spanish Yucatan: “...los mayas no fueron conquistados 
lingüísticamente; más bien ellos resultaron conquistadores en este caso”. This contact, which takes the form of daily interaction between Spanish-speakers and Mayan-speakers, many of whom work as muchachas de casa, nannies or day laborers, has resulted in the majority of yucatecos being exposed to Mayan or Mayaninfluenced Spanish from an early age (Lipski 1994: 81). The existence of a single widespread indigenous culture throughout the peninsula has helped to foster a sense of distinctiveness among yucatecos with regard to the rest of Mexico. Two other interrelated factors with important linguistic consequences are the historical isolation of the Yucatan peninsula and the concomitant rise of a strong sense of local identity among residents.

Throughout most of colonial and early post-colonial history, Yucatan existed as a de facto autonomous state (Quezada 2001). With boat travel long and difficult, and rail service between the Yucatan and the rest of Mexico not available until the 1960's (Quezada 2001: 238), the peninsula spent most of its history isolated geographically, culturally, and linguistically, from the surrounding regions. Although officially a part of the Audiencia de México from 1560 (Quezada 2001: 74-75), in reality Yucatan dealt directly with Spain instead of with the colonial seat in Mexico City. For example, the governor and captain general of Yucatan was appointed directly by the Crown in Spain, rather than by the viceroy in Mexico (Mosely 1980: 94). The lack of regular contact with Mexico led, linguistically, to Yucatan Spanish sharing many traits in common with Central American varieties, rather than with the Spanish of central Mexico (Lipski 1994: 274). The sense of historical and cultural distinctiveness is seen in the repeated armed rebellions against Mexican authority which led on two different occasions in the mid 1800's to the secession of Yucatan from the Republic of Mexico (Quezada 2001). These civil wars had the effect of further reinforcing a sense of regional identity. The lack of connectedness to the rest of Mexico was such that that the government of Yucatan even offered itself for annexation to the United States in exchange for military protection from Mexico, in much the same way as another renegade republic, Texas (Alisky 1980: 249). It was only the need for Mexican military assistance during the Mayan uprising known as la guerra de las castas that permanently reincorporated Yucatan to the Mexican state. Thus, while the República de Yucatán only governed for a few years, the feeling among residents that Yucatan is somehow different from the rest of the country remains. Importantly, there is a feeling among many yucatecos that they are different from their compatriots in the rest of Mexico, a sense of regional identity based not only on historical and political facts, but also by cultural differences predicated on the Mayan past (as opposed to Aztec), as well as the economic boom that accompanied the rise of large henequen plantations in the 19th and early 20th centuries, turning Yucatan into one of the richest areas in Mexico. Interestingly, Yucatan again petitioned for union with the United States during the 
Mexican Revolution, on the basis that Yucatan shared more in common with that country than with the rest of Mexico (Joseph 1980: 143). Even today throughout Merida it is not unusual to see popular items (such as bumper stickers, $t$-shirts and flags) expressing one's loyalty to the patria chica of Yucatan.

The isolation in which Yucatan (and YS) developed has naturally led to a strong sense of local identity on the part of speakers; Michnowicz (2006b: 16) found that a majority of speakers surveyed identified themselves as "more Yucatecan" than Mexican, and no speakers said they felt more affinity to Mexico than to Yucatan. Similar to attitudes toward regional language in some other areas, such as the Appalachian region of the US, speakers of YS are proud of their dialect, even though some admit that they do not speak 'correctly' vis-à-vis standard Spanish (Michnowicz 2006b). Importantly, this isolation is rapidly diminishing as increased tourism and industry bring immigrants from other areas, but especially from Yucatan's traditional cultural and political rivals in central Mexico. In the decade from 1990-2000, Yucatan saw an increase of 43\% in immigration from Mexico City, with Merida, the state capital, experiencing an even greater increase in immigration from the Distrito Federal: $46 \%$ more immigrants than in the previous decade (INEGI 2000). As of the 2000 census, the latest date for which this data is available, there were 22,958 natives of the Distrito Federal (i.e. Mexico City) living in Merida, representing the largest immigrant group in the city (INEGI 2000). As a result of this immigration, there are neighborhoods in Merida primarily composed of transplants from central Mexico, who are referred to in Yucatan as waches (or huaches), a pejorative term for people from central Mexico. The residents of Merida are acutely aware of the new arrivals, and blame the immigrants for increased traffic, crime, pollution, as well as for a loss of regional customs (Michnowicz 2006b). One participant from the present study talking about crime notes:

[esas cosas] no sucedían hace cinco años aquí, pero yo pienso que esas personas son gente de fuera; no son de, de Mérida. Entonces, tal vez están comenzando a formar sus bandas por aquí, no sé...

Another speaker explains the traditional resentment that exists between Yucatecans and central Mexicans, referring to people from Mexico City with the term waches:

...ves que todavía aquí a los mexicanos les llaman waches...no los soportan mucho. O sea...los yucatecos prefieren más tratar con un americano, por ejemplo, que con un wach, como le llaman...

Another speaker refuses to identify with the recent immigrants and any shared sense of nationality, maintaining that "...no nos decimos nosotros mexicanos, decimos yucatecas. Yucateca, no soy mexicana...” 
The Yucatan peninsula has also experienced an influx of tourists and manufacturing industries over the past 30 years. Tourism, while centered in Cancun in the neighboring state of Quintana Roo, has also had an important effect within the state of Yucatan. For example, most of the major Mayan ruins in Mexico (e.g. Uxmal, Chichén Itzá) are located within Yucatan, and the tourism based around these sites has increased daily contact between yucatecos and speakers from the rest of Mexico as well as from outside the country. With regard to industry, Biles (2004: 520-528) shows that Yucatan has experienced a substantial increase in maquiladora construction during the 1990's, expanding from 13 factories to 145 located throughout the state. These factories are owned, for the most part, by a combination of local, domestic, and foreign businesses and the creation of these globalized maquiladoras has increased the contact that many yucatecos have with speakers from other regions.

In the light of the numerous social and economic changes within Yucatan over recent decades, regional identity continues to be an important factor in how $y u$ catecos relate to other Spanish-speakers, and with other Mexicans in particular. I will argue in section 8 that this strong regional identity may have linguistic consequences for some speakers in Merida.

\section{Previous studies on final nasals in Yucatan Spanish}

Several studies over the last 40 years have analyzed nasal variants in YS, most focusing on the regional variant $[\mathrm{m}]$. YS nasals have received attention because the change $/ \mathrm{n} />[\mathrm{m}]$ is found only rarely in Spanish dialects, and contradicts most theories of markedness, which allow only coronal (or dorsal) consonants in coda position (but see Hume \& Tserdandelis 2002 and Hume 2003 who argue that labial unmarkedness cannot be ruled out a priori, providing evidence that labial patterns as unmarked in some languages (Sri Lankan Portuguese Creole and Kiribatese)). Additionally, it has been widely assumed that contact with Mayan has resulted in non-standard forms in YS, but this has rarely been tested empirically. The earliest studies on YS make no mention of nasal variation (Barrera Vasquez 1937; Nykl 1938; Suarez 1945/1979; Mediz Bolio 1951), and it is not until Alvar's (1969) study that final nasals are addressed in the literature. In his study based on 10 interviews with speakers from throughout the peninsula, Alvar (1969: 168) notes that $[\mathrm{m}]$ occurs in the dialect with "abrumadora frecuencia", and that labial $[\mathrm{m}]$ is one of the primary factors in distinguishing YS from surrounding dialects. In contrast, Alvar also found final nasals to be realized as [n] among monolingual Spanish speakers, along with "frequent" cases of nasal deletion (1969: 168). Alvar argues that nasal velarization and deletion are processes internal to Spanish, 
linking Yucatan with other areas of Mexico and Spain, but that $[\mathrm{m}]$ is an indigenous sound with its roots in the Mayan language (1969: 169). Cassano (1977: 105113 ) only mentions YS nasals briefly, implying that since $[\mathrm{m}]$ is also found in parts of Colombia, the process must be an internal development of Spanish and not due to language contact. Yager (1982) undertook recorded interviews of 18 men and women from different socioeconomic classes and different age groups. Yager found regional $[\mathrm{m}]$ to be the most common variant, followed by frequent [ $\mathrm{n}$ ], then alveolar [n], and occasional $ø ;[n]$ and [n] were found to usually be accompanied by nasalization of the preceding vowel (1982: 77-78). He also reports occasional instances of $[\mathrm{m}]$ word finally but in the middle of an utterance, such as in 'Yucatán que' [ju.ka.'tam.ke], where the expected processes of nasal assimilation fails to obtain (Yager 1982: 78). Citing the existence of a similar [n]-[m] alternation in Mayan and the rarity of $[\mathrm{m}]$ outside of Yucatan, Yager concludes that this process is most likely due to Mayan influence (p. 80). García Fajardo (1984) undertook a study of the speech of Valladolid, a city on the eastern edge of the state of Yucatan. Employing recorded interviews of 39 speakers, balanced for socioeconomic class, gender and age, García Fajardo (1984: 75-77) found that [m] was a common variant in all of her subjects, although the overall frequency of labialization was not high, with a majority of tokens being alveolar [n]. In her corpus, [m] arose in 34 of 39 speakers, with a frequency range of $5 \%$ to $40 \%$, with no clear correlation to socioeconomic class, age, or gender; $72 \%$ of these speakers produced $[\mathrm{m}]$ with a frequency of less than $20 \%$ (p. 76). She also notes that the alveolar and labial nasals may be co-articulated $\left(\left[\mathrm{n}^{\mathrm{m}}\right]\right)$, although this possibility was not as frequent as full labialization. García Fajardo reports low frequencies of both $[\mathrm{n}]$ and $ø$ in her informants. Lope Blanch (1987), synthesizing data from the Atlas lingüistico de México (ALM) collected during the 1970's, dedicates parts of several chapters to a discussion of $[\mathrm{m}]$ in YS. Based on the linguistic questionnaires and recorded conversations from the ALM, Lope Blanch found the most frequent nasal in recorded conversations to be [n] (73\%), followed by [m] (12\%), [n] (8\%), and $\varnothing ~(2 \%) ~(p .42)$. The frequency of $[\mathrm{m}]$ more than doubled, however, in the questionnaire data to $25 \%$ (p. 42). Since the linguistic questionnaire was essentially a word-naming task in which every utterance is necessarily followed by a pause, Lope Blanch concludes that $[\mathrm{m}]$ is most frequent in absolute final position, and that brief pauses that occur in normal conversation may not be long enough to trigger the pronunciation of $[\mathrm{m}]$ (p.47). With regard to Mayan influence on YS [m], Lope Blanch notes that the change $/ \mathrm{n} />[\mathrm{m}]$ is primarily a process internal to Spanish, citing its occurrence in other regions of Mexico, Argentina, and Spain (p.61). He also argues, however, that in no other part of the Spanish-speaking world does $[\mathrm{m}]$ achieve the level found in YS, and that this process coincides to a high degree with frequencies and patterns found in Mayan. Therefore he concludes that YS [m] did not develop 
independently of Mayan influence, but rather that it is a natural process of Spanish that has been favored by contact with Mayan (p.62). Lope Blanch hypothesizes that $[\mathrm{m}]$ arose first among Mayan-Spanish bilinguals in Yucatan, and was later passed on to monolingual Spanish-speakers through contact (p.63). Regarding $[\mathrm{m}]$ and other regional phonological processes, Lope Blanch argues that the inherent variability in YS as well as the lack of strong normative pressures due to the isolation in which YS developed have combined to permit the change $/ \mathrm{n} />[\mathrm{m}]$ (p. 63). Yager (1989) undertook a sociolinguistic study of YS nasals based on recorded free conversations with 25 speakers. Yager (1989) found that both [n] and $[\mathrm{m}]$ occurred at a frequency of $41 \%$, a frequency much higher than the $12 \%[\mathrm{~m}]$ found by Lope Blanch (1987), a difference which Yager attributes to methodological differences in the ways that final nasals were counted. Yager found more $[\mathrm{m}]$ production in women than in men (50\% vs. $32 \%)$, and an increase in $[\mathrm{m}]$ across age groups (34\% for older speakers, $40 \%$ for middle aged speakers, and 55\% for younger speakers) (91). Additionally, Yager (1989) found the highest rates of [m] among middle class speakers (47\%), followed by lower class (41\%) and higher class participants (35\%) (93). Yager ran one test of statistical significance, and found no significant difference for $[\mathrm{m}]$ production between monolingual Spanishspeakers and speakers of Mayan. He attributes the increase in [m] across age groups to the correlation of the labial with local prestige among middle class female speakers, with $[\mathrm{m}]$ later spreading to lower class men (p.94). Based on his findings, Yager concludes that $[\mathrm{m}]$ is accepted among upper class speakers and suggests that its use may expand in the future (p. 94). Pfeiler (1992) examined YS nasals in several different areas of Merida, based on recorded conversations with 32 speakers balanced for age and gender. Pfeiler found that absolute final nasals varied according to the type of following pause, with an absolute or explanatory pause (to provide more information) both triggering $[\mathrm{m}]$, while a 'potential pause (depending on the will of the speaker)' conditioned [n]. An enumerative pause (preceding a list) produced variation between $[\mathrm{n}]$ and $[\mathrm{m}]$ (p.119). Additionally, while women produced more [m] than men, Pfeiler (1992) found no difference based on social class, determined by years of formal education (p.119). Finally, Michnowicz (2006a) conducted a 'rapid and anonymous' survey (see Labov 1966) of final nasals in the phrase 'Avenida Colón', a major street in Merida. Following the methodology established by Labov (1966), I asked people walking along Avenida Colón what the name of the street was. Pretending to not have heard or understood, I then asked them to repeat their answer, taking the first utterance to represent normal speech and the second to represent careful speech. Overall, participants pronounced the word Colón as [ko'lóm] with a frequency of 74\%, a high frequency vis-à-vis other studies, leading the author to hypothesize that labial [m] in YS is to some extent lexicalized. Additionally, for women [m] was more frequent in normal 
speech than in emphatic speech, while men showed no difference between the two utterances. Different from other studies, the results showed more $[\mathrm{m}]$ among men, a discrepancy which is attributed to methodology, with men being less 'careful' than women when speaking to another (unknown, foreign) man on the street.

In summary, previous studies show a wide range of variation in final nasals, attesting both to the differing methodologies and the "intensísimo poliformismo" (Lope Blanch 1987: 8) of YS. With few exceptions (see Yager 1982 and Michnowicz 2006a), previous studies agree that $[\mathrm{n}]$ is the overall preferred variant in YS, with [m] a second option utilized by many, if not most, speakers of the dialect, albeit with varying frequencies. Previous studies are not conclusive regarding the roles of social class and bilingualism on the production of nasal variants. The present study, therefore, seeks to address the possible role of these and other factors on nasal choice in YS. In the next section we will examine the methodology of the present study, designed to provide quantitative answers to the question of final nasal preference in YS.

\section{Methodology}

Subjects for the present study were interviewed over a two month period in or around Merida, the capital of Yucatan. Initial contacts were made via friends and university faculty in Merida, and the researcher was introduced as a 'friend of a friend' in most cases. The researcher lived with a local family, through which many contacts were made, and participated in daily life within the neighborhood and throughout the city. Data was collected via recorded sociolinguistic interviews lasting approximately a half an hour with 40 native speakers of YS. An attempt was made to minimize the 'researcher's paradox' (Labov 1984) by allowing the speaker to guide the conversation when possible and by suggesting topics that led the participant to reminisce about his/her families and friends. Frequent topics included family life, memories about a speaker's wedding or children and local customs and traditions. Speakers were assigned to different social groups based on a linguistic background questionnaire given at the end of the interview. Participants were selected based on gender (men, $\mathrm{n}=19$; women, $\mathrm{n}=21$ ), age group (19-29, $\mathrm{n}=11$; $30-49, \mathrm{n}=13 ; 50+, \mathrm{n}=16$ ), social class (lower, $\mathrm{n}=15$; higher, $\mathrm{n}=25$ ), and language (Mayan bilinguals, $n=21$; monolingual Spanish-speakers, $n=19$ ). The age groups are taken to represent three life stages (young adulthood, middle age, seniors). The two social classes are based on occupation and education: the lower class subjects did not complete high school and were working as market vendors, house cleaners, janitors, and construction workers; the higher social class subjects completed at least high school and worked in professional or semi-professional fields, or were 


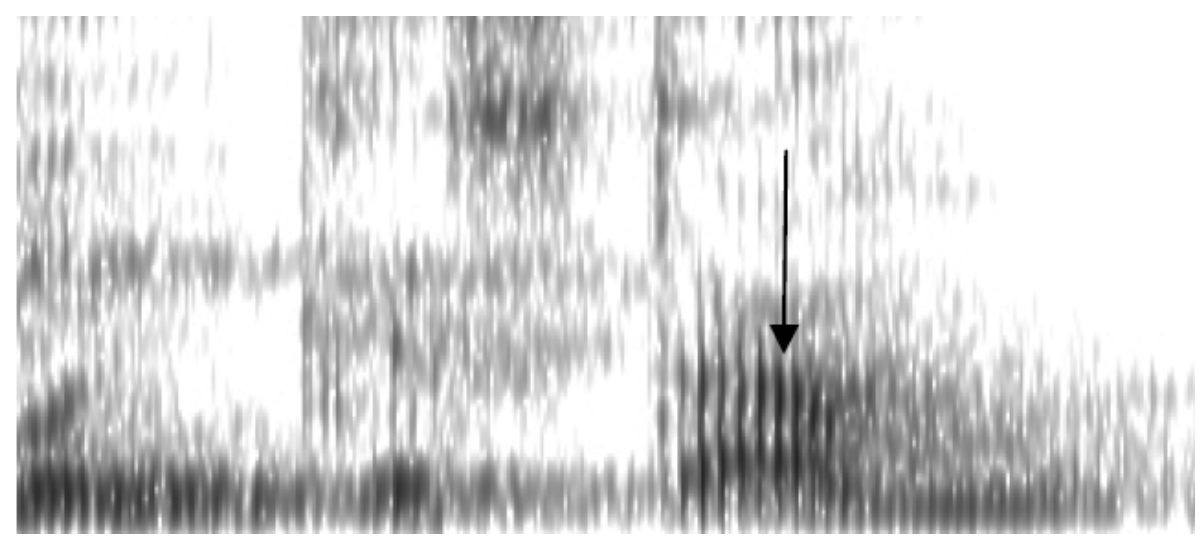

Figure 1. Spectrogram for en que están. The arrow indicates falling F1 and F2 formant transitions into the consonant $[\mathrm{m}]$.

college students. Occupations for higher social class subjects included architect, business, school administrator, engineer, lawyer, teacher, nurse, and secretary. For the language groups, Mayan speakers were either fluent $(n=13)$, or passive speakers $(n=8)$. Passive speakers were identified as the children or grandchildren of fluent Mayan speakers that grew up hearing Mayan in the home and can at least understand a conversation in that language, even though they may reply in Spanish.

The recordings were transcribed orthographically in order to identify each coda nasal token. Each token was listened to and classified by the author as alveolar [n], bilabial [m], velar [n] or deleted $\emptyset$. The tokens were classified categorically; that is, the rare instance of a co-articulation or unclassifiable nasal was discarded from analysis. ${ }^{1}$ The relative weakness of articulatory transitions into coda consonants (see Winters 2000) makes the point of articulation difficult to determine via spectrographic analysis; still, labials can be distinguished from coronals and dorsals by a falling transition in both F1 and F2, whereas coronal and dorsal consonants show a rising F2 transition (Kent \& Read 1992). The falling transitions into $[\mathrm{m}]$ can be seen in Figure 1, a spectrogram made using Praat from the present corpus. In the present study, spectrographic analysis was only undertaken if there was a question about the articulation of a particular token. This occurred infrequently, and the vast majority of tokens were easily classifiable based on listening alone. The nasal tokens were coded for linguistic and social factors for multivariate statistical analysis, conducted using GoldVarb 2001 for Windows. 


\section{Results: Linguistic factors}

The results of this study demonstrate that nasal variants in Yucatan Spanish are sensitive to linguistic factors, such as phonetic context. First, previous studies have observed that the regional variant $[\mathrm{m}]$ occurs primarily in absolute final position, that is, before a pause, but this observation has not been tested empirically (Lope Blanch 1987; Yager 1989; Michnowicz 2006b). In order to test this observation, an initial frequency analysis was conducted on all 14,702 coda nasal consonants in the present corpus. The results of this initial analysis are presented in Table 1.

Table 1. Frequencies of nasal variants in non-neutralizing contexts

\begin{tabular}{lrc}
\hline Variant & Tokens & Percentage \\
\hline$[\mathrm{n}]$ and standard assimilation & 14,229 & $97 \%$ \\
{$[\mathrm{~m}]$} & 292 & $2 \%$ \\
{$[\varnothing]$} & 64 & $0 \%$ \\
{$[\mathrm{n}]$} & 117 & $1 \%$ \\
\hline Total & 14,702 & $100 \%$ \\
\hline
\end{tabular}

As these data demonstrate, speakers of Yucatan Spanish overwhelmingly follow pan-Hispanic norms of coda nasal assimilation, in which word-internal nasal consonants share the point of articulation with a following consonant; in final position or preceding a vowel, default [n] arises (see Hualde 2005; Teschner 2000 and many others). The appearance of standard alveolar [n] finally and cases of expected nasal assimilation internally account for $97 \%$ of nasal consonants in coda position. The regional $[\mathrm{m}]$ occurs very infrequently across all the data, totaling only $2 \%$ of all (non-assimilating) coda nasals, while [n] and deletion account for the other $1 \%$. Since previous studies hypothesized that $[\mathrm{m}]$ occurs primarily in absolute final position (i.e. before a pause, when nasal assimilation cannot occur but in which a 'default' nasal such as standard [n] or the frequent [n] will arise(see Hualde 2005)), a second frequency analysis was conducted on the 1091 nasal consonants in this context. The data presented in Table 2 confirm earlier observations of Yucatan Spanish: the labial variant, while not occurring frequently across the data, does account for a quarter of nasal tokens in absolute final position.

In addition a multivariate statistical analysis (VARBRUL) was run using GoldVarb for Windows on all 14,702 tokens comparing absolute final and other coda positions. Results indicate that absolute final position strongly favors $[\mathrm{m}]$ production (f.w. 0.994), compared to other coda positions (f.w. 0.399). Although the factor weights indicate that non-assimilated $[\mathrm{m}]$ occurs very little outside of absolute final position, the present corpus does contain 18 possible tokens of $[\mathrm{m}]$ in word or phrase internal contexts, accounting for $1.6 \%$ of the total bilabial tokens. 
Table 2. Frequencies for each nasal variant in absolute final position

\begin{tabular}{lcc}
\hline Variant & Tokens & \% of total \\
\hline$[\mathrm{n}]$ & 663 & $61 \%$ \\
{$[\mathrm{~m}]$} & 274 & $25 \%$ \\
{$[\mathrm{n}]$} & 95 & $9 \%$ \\
$\varnothing$ & 59 & $5 \%$ \\
\hline
\end{tabular}

Example tokens clearly produced with word or phrase internal [m], where nasal assimilation or resyllabification fail to apply, include mayormente 'mostly' [ma.'jor. mem.te], confundió 'he confused' [kon.fum.'dió], saben como 'they know how' [sa. ßem.ko.mo], postración en 'prostration in' [pos.tra.'sjom.en], and chichón chichón 'head bump' (repeated twice with no pause in between) [tfi.'tfom.tfi.'tfom]. Thus in some cases internal $/ \mathrm{n} /$ fails to assimilate to a following consonant, while in the one case of internal $[\mathrm{m}]$ before a vowel (postración en - compare standard [pos. tra.'sjo.nen]), final $/ \mathrm{n} /$ fails to resyllabify into the onset of the following syllable. However, given that labialization occurs overwhelmingly in absolute final position, further analysis of internal $[\mathrm{m}]$ is reserved for future investigation. The rest of this analysis, therefore, focuses on comparing nasal tokens in absolute final position only. The frequencies for each of the nasal variants in absolute final position are also shown in Table 2.

Again, we see that while alveolar [n] is still the preferred nasal, confirming most previous findings, regional [m] now accounts for $25 \%$ of the tokens. Interestingly, the widespread variant [ $\mathrm{\eta}]$, common in many other dialects, accounts for only $8 \%$ of absolute final tokens, an unexpected result given that Yucatan is surrounded by varieties of Spanish that prefer the velar nasal in this position (Lipski 1994), and that Yucatan has previously been reported to be a velarizing area (Canfield 1981).

Next, a series of VARBRUL analyses was conducted on each of the nasal variants with the goal of discovering other linguistic factors that may influence a speaker's usage. Linguistic factors examined included the origin of the word (Mayan root vs. Spanish root), the word class (noun, adjective/adverb, verb, preposition, determiner), the syllable type (stressed vs. unstressed) and the preceding vowel height (low, mid, high). The results of the statistical analysis for each variant are shown in Tables 3, 4, 5 and 6.

First, the alveolar variant [n], is favored by unstressed syllables (0.597), as well as words belonging to the classes adjective/adverb (0.604), verb (0.532), and deter$\operatorname{miner}^{2}(0.864)(p=0.007)$. The only linguistic factor chosen as significant for the regional $[\mathrm{m}]$ is syllable type, with stressed syllables slightly favoring the labial variant (0.559), distinguishing the labial from the alveolar. Velar [n] is favored by the word classes noun (0.550), verb (0.571), and preposition (0.768), stressed syllables 
Table 3. [n]: VARBRUL weights for significant linguistic factors Not significant: Word origin, preceding vowel

\begin{tabular}{lllll}
\hline Factor groups & Factors & n & \% of total & FW \\
\hline \multirow{4}{*}{ Word class } & Noun & $212 / 429$ & $49 \%$ & 0.431 \\
& Adj/Adv & $131 / 198$ & $66 \%$ & 0.604 \\
& Verb & $262 / 372$ & $70 \%$ & 0.532 \\
& Prep. & $43 / 76$ & $56 \%$ & 0.367 \\
\multirow{5}{*}{ Syllable stress } & Det. & $15 / 16$ & $93 \%$ & 0.864 \\
& Stressed & $367 / 674$ & $54 \%$ & 0.440 \\
& Unstressed & $296 / 417$ & $70 \%$ & 0.597 \\
\hline
\end{tabular}

Input: $0.616 \quad \mathrm{X}^{2} /$ cell: $0.2977 \quad p=0.007$

Total $X^{2}: 2.6790 \quad \log$ likelihood: -701.636

Table 4. [m]: VARBRUL weights for significant linguistic factors

Not significant: Word origin, word class, preceding vowel

\begin{tabular}{lllll}
\hline Factor groups & Factors & n & \% of total & FW \\
\hline \multirow{2}{*}{ Syllable stress } & Stressed & $198 / 674$ & $29 \%$ & 0.559 \\
& Unstressed & $76 / 417$ & $18 \%$ & 0.405 \\
\hline
\end{tabular}

Input: $0.247 \quad \mathrm{X}^{2} /$ cell: $0.0001 \quad p=0.000$

Total $X^{2}: 0.0002 \quad \log$ likelihood: -606.091

Table 5. [n]: VARBRUL weights for significant linguistic factors

Not significant: Word origin

\begin{tabular}{lllll}
\hline Factor groups & Factors & $\mathbf{n}$ & \% of total & FW \\
\hline \multirow{5}{*}{ Word class } & Noun & $52 / 429$ & $12 \%$ & 0.550 \\
& Adj/Adv & $5 / 198$ & $2 \%$ & 0.193 \\
& Verb & $29 / 372$ & $7 \%$ & 0.571 \\
\multirow{5}{*}{ Syllable stress } & Prep. & $9 / 76$ & $11 \%$ & 0.768 \\
& Det. & $0 / 16$ & knockout & - \\
\multirow{5}{*}{ Preceding vowel } & Stressed & $67 / 674$ & $9 \%$ & 0.596 \\
& Unstressed & $28 / 417$ & $6 \%$ & 0.343 \\
& High & $2 / 81$ & $2 \%$ & 0.183 \\
& Low & $56 / 697$ & $8 \%$ & 0.497 \\
\hline
\end{tabular}

Input: $0.073 \quad \mathrm{X}^{2} /$ cell: $3.3462 \quad p=0.010$

Total X²: $56.8852 \quad \log$ likelihood: -303.472

Table 6. Ø: VARBRUL weights for significant linguistic factors

Not significant: Word origin, syllable stress, preceding vowel

\begin{tabular}{lllll}
\hline Factor groups & Factors & n & \% of total & FW \\
\hline \multirow{4}{*}{ Word class } & Noun & $35 / 429$ & $8 \%$ & 0.624 \\
& Adj/Adv & $7 / 198$ & $3 \%$ & 0.407 \\
& Verb & $13 / 372$ & $3 \%$ & 0.404 \\
& Prep. & $4 / 76$ & $5 \%$ & 0.509 \\
& Det. & $0 / 16$ & knockout & - \\
\hline
\end{tabular}

Input: $0.051 \quad \mathrm{X}^{2} /$ cell: $0.0000 \quad p=0.018$

Total X²: $0.0001 \quad \log$ likelihood: -223.559 
(0.596), and the preceding low vowel /a/ (0.584). Finally, for $\emptyset$ only word class was selected, with nouns (0.624) and prepositions (0.509) favoring deletion. Word origin (Mayan vs. Spanish - primarily place names or regional foods, customs, etc.) was not selected as significant for any of the variants. Syllable stress is the only factor selected as significant for the three most common variants, with unstressed syllables favoring [n], and stressed syllables favoring $[\mathrm{m}]$ and $[\mathrm{n}]$.

\section{Results: Social factors}

In this section I will present the results of several VARBRUL analyses performed on the data in order to determine what role, if any, social factors have on final nasal selection in Yucatan Spanish. The social factors examined are gender, age (19-29, $30-49,50+$ ), social class (higher vs. lower), and language (monolingual Spanish, bilingual Mayan). Initial cross-tabulation analyses showed a strong interaction between social class and language group. That is, knowledge of Mayan and social class as based on education and occupation are not independent of one another in the present corpus. All monolingual Spanish-speakers studied here belong to the higher social class group. Likewise, all lower social class speakers studied here are passive or active speakers of Mayan. Note that the opposite is not true; there are Mayan speakers among the higher social group in this study. This distribution captures two important social facts in Merida. First, lower class speakers are very likely to have an indigenous background and speak Mayan. Second, the socio-economic status of some Mayan-speakers is beginning to improve, with some Maya now able to obtain education and jobs previously reserved for the Spanish-speaking elite. Given the strong interaction between language and social group, these two groups have been combined into a single variable for the purposes of analysis.

Each nasal variant was subjected to one-level binomial and step-up/step-down binomial analyses, comparing each of the nasal variants to the others to establish the relative impact of each of the factors on nasal variation and to determine which factor groups contribute significantly to the production of each nasal variant. The significant results for each analysis are presented in Tables 7, 8, 9, and 10.

First, the results show no significant effect for gender on the standard [n]. The other variants do show an effect for gender, however, with women producing more $[\mathrm{m}]$, and men more $[\mathrm{n}]$ and $\varnothing$. With regard to age, only [n] and [m] show significant effects, with older speakers favoring [n] and middle age and younger speakers favoring $[\mathrm{m}]$. Finally, all of the variants show a significant effect for social class/language; $[n]$ is favored by monolingual Spanish-speakers, all of which belong to the higher social class. The labial $[\mathrm{m}]$ is favored by higher social class Mayan-speakers, with lower class Mayan-speakers being nearly neutral for [m] 
Table 7. [n]: VARBRUL weights for significant social factors Not significant: Gender

\begin{tabular}{lllll}
\hline Factor groups & Factors & $\mathbf{n}$ & \% of total & FW \\
\hline \multirow{3}{*}{ Age } & $19-29$ & $160 / 272$ & $58 \%$ & 0.494 \\
& $30-49$ & $183 / 360$ & $50 \%$ & 0.433 \\
& $50+$ & $320 / 459$ & $69 \%$ & 0.556 \\
Social group/ & Lower - Spanish & No speakers & - & - \\
language & Lower- Mayan & $197 / 346$ & $56 \%$ & 0.467 \\
& Higher - Spanish 382/553 & $69 \%$ & 0.567 \\
& Higher-Mayan & $84 / 192$ & $43 \%$ & 0.369 \\
\hline
\end{tabular}

Input: 0.612

$\mathrm{X}^{2} /$ cell: $0.6996 \quad p=0.011$

Total $X^{2}: 5.5967 \quad \log$ likelihood: -705.578

Table 8. [m]: VARBRUL weights for significant social factors

All factor groups significant

\begin{tabular}{lllll}
\hline Factor groups & Factors & $\mathbf{n}$ & \% of total & FW \\
\hline \multirow{2}{*}{ Gender } & Male & $126 / 566$ & $22 \%$ & 0.444 \\
& Female & $148 / 525$ & $28 \%$ & 0.561 \\
Age & $19-29$ & $72 / 272$ & $26 \%$ & 0.526 \\
& $30-49$ & $131 / 360$ & $36 \%$ & 0.621 \\
\multirow{4}{*}{ Social group/ } & Lower- Mayan & N1/459 & $15 \%$ & 0.389 \\
language & Higher - Spanish & $109 / 553$ & - & - \\
& Higher-Mayan & $74 / 192$ & $38 \%$ & 0.504 \\
& Lower - Spanish & $19 \%$ & 0.458 \\
\hline
\end{tabular}

Input: $0.237 \quad \mathrm{X}^{2} /$ cell: $0.9220 \quad p=0.012$

Total $X^{2}: 13.8298 \quad \log$ likelihood: -583.130

Table 9. [n]: VARBRUL weights for significant social factors

Not significant: Age

\begin{tabular}{lllll}
\hline Factor groups & Factors & $\mathbf{n}$ & \% of total & FW \\
\hline \multirow{2}{*}{ Gender } & Male & $66 / 566$ & $11 \%$ & 0.584 \\
& Female & $29 / 525$ & $5 \%$ & 0.409 \\
& Lower - Spanish & No speakers & - & - \\
Social group/ & Lower- Mayan & $30 / 346$ & $8 \%$ & 0.510 \\
language & Higher - Spanish & $37 / 553$ & $6 \%$ & 0.452 \\
& Higher-Mayan & $28 / 192$ & $14 \%$ & 0.620 \\
\hline Input: 0.080 & $\mathrm{X}^{2} /$ cell: 0.4734 & $p=0.047$ & & \\
Total X ${ }^{2}: 2.8406$ & $\log$ likelihood: -312.902 & &
\end{tabular}

(0.504). Velar [n] is favored by Mayan-speakers of both social classes, most strongly by those belonging to the higher class (0.620). Deletion ( $\varnothing)$ occurs most often among lower class Mayan-speakers (0.621). 
Table 10. [ø]: VARBRUL weights for significant social factors

Not significant: Age

\begin{tabular}{lllll}
\hline Factor groups & Factors & $\mathbf{n}$ & \% of total & FW \\
\hline \multirow{2}{*}{ Gender } & Male & $39 / 566$ & $6 \%$ & 0.582 \\
& Female & $20 / 525$ & $3 \%$ & 0.412 \\
& Lower - Spanish & No speakers & & \\
Social group/ & Lower- Mayan & $28 / 346$ & $8 \%$ & 0.621 \\
language & Higher - Spanish & $25 / 553$ & $4 \%$ & 0.479 \\
& Higher-Mayan & $6 / 192$ & $3 \%$ & 0.344 \\
\hline
\end{tabular}

Input: $0.049 \quad \mathrm{X}^{2} /$ cell: $0.8217 \quad p=0.016$

Total X²: $4.9303 \quad \log$ likelihood: -222.734

\section{Discussion}

As noted previously, the alveolar [n] is the preferred variant overall, accounting for $60 \%$ of the total absolute final nasals. In spite of its status as the most common variant, however, [n] does demonstrate sensitivity to social factors, occurring significantly more among older speakers and monolingual Spanish-speakers. Crosstabulation analyses reveal that older monolingual Spanish-speakers produce the highest frequencies of [n], 72\%. This is followed closely by young monolinguals (69\%), and then by middle age monolinguals (58\%). As seen in Tables 7 and 8, middle age speakers produce significantly less $[\mathrm{n}]$ and more $[\mathrm{m}]$, accounting for this u-shaped distribution. Higher class Mayan-speakers show the lowest rates of [n], with $39 \%$ for young speakers and $47 \%$ for middle age speakers respectively. Note that there are no age 50+ higher class Mayan-speakers in the corpus, again reflecting the traditional stratification of Merida society that has only begun to break down in the last 30 years. A comparison of factor weight range in Table 7 shows that social class/language is the most important factor for [n], followed by age. Separate step up/step down analyses found the age difference between older and middle age speakers to be significant $(p=0.035)$, while the difference between middle age and younger speakers was not significant. With regard to age, therefore, the conditioning factor for $[\mathrm{n}]$ is age $>50$. In sum, $[\mathrm{n}]$ is favored both by higher social class, Spanish monolingualism, and age over 50, which speaks to its status as the standard, conservative variant in YS.

One of the 'non-standard' variants, $[\mathrm{m}]$ shows sensitivity to all of the social factors examined here. Cross-tabulation analyses reveal that, as expected from the factor weights in Table 8, women produce the highest rates of [m] across both age and class/language groups. Likewise, age 30-49 speakers show the most [m] across both gender and class/language groups. The highest rate of $[\mathrm{m}]$ in the analysis is found among higher class Mayan-speaking women, with 52\% [m]. Compare this 


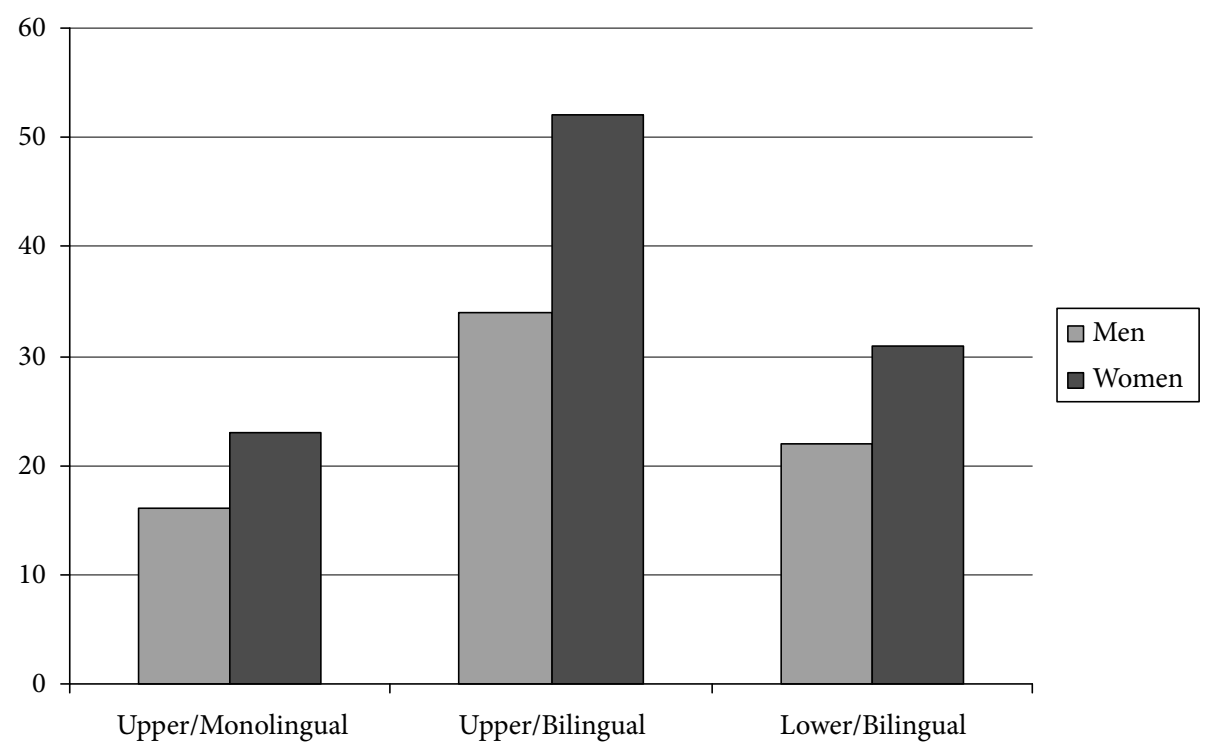

Figure 2. Cross tabulations of gender and class/language for [m].

frequency with that of men from the same groups, $34 \%$ [m], a gender-based difference of 18\%, seen in Figure 2.

As seen in Figure 3, [m] increases in frequency sharply across age groups, from older to middle age speakers (older women 17\%, older men 14\%; middle aged women $40 \%$, middle aged men $33 \%$ ), an increase of $23 \%$ and $19 \%$ respectively over one generation. The use of $[\mathrm{m}]$ appears to peak among the middle age group, and then decreases in frequency among young speakers (32\% for women vs. $22 \%$ for men), a decrease of $8 \%$ and $10 \%$ respectively, again over one generation. Younger speakers, in spite of this apparent decrease, still use almost twice as much $[\mathrm{m}]$ as do speakers of their grandparents' generation. Separate step up/ step down analyses found that the age difference between older and middle age speakers was significant $(p=0.000)$, while the difference between middle age and young speakers was not. That is, in spite of the apparent peak among middle age yucatecos, young and middle age speakers behave in a statistically identical manner regarding $[\mathrm{m}]$; therefore, the conditioning factor is age $<50$, the opposite of the finding regarding age for $[n]$ seen above.

Additionally, speaking Mayan was found to correlate significantly with use of $[\mathrm{m}]$, while $[\mathrm{n}]$ arose significantly more among monolingual Spanish-speakers. This result lends support to earlier claims that [m] was at least partly due to contact with Mayan, although further data is needed to make a strong claim. But note that it has been reported that $[\mathrm{n}]$ and $[\mathrm{m}]$ are in "free variation" word finally in Yucatec Mayan (Romero 1963; Bolles \& Bolles 2001), also giving credence to contact 
theories for $[\mathrm{m}]$. Regarding the role of Mayan language, these results agree with Lope Blanch's (1987: 63) hypothesis that [m] arose first among Mayan-Spanish bilinguals due to interference from the indigenous language, and later was extended to the monolingual Spanish-speaking population in Yucatan. They disagree, however, with Yager (1989), who found no statistical correlation between speaking Mayan and the use of $[\mathrm{m}]$. As noted in section 2 however, the sociolinguistic history of Mayan-Spanish contact does indicate that Mayan is in a position of having influenced YS. Mayan, once spoken by a majority of the population which shifted (and continues to do so today) to Spanish via long periods of bilingualism over a period of several centuries could have influenced Spanish as the shifting majority failed to completely match native Spanish norms (see Thomason 2001; Michnowicz in press). Still, while these results demonstrate that Mayan-Spanish bilingualism is a factor in [m] production, a detailed study of the possible role of contact is reserved for future research.

With regard to the ranking of social factors for [m], a comparison of factor weight range in Table 8 shows that age is the most important factor in determining $[\mathrm{m}]$ use, followed by class/language and gender.

As these and previously discussed data make clear, it is primarily middle aged, higher class, Mayan-speaking women who account for the increase in frequency of $[\mathrm{m}]$ from older to middle aged speakers.

Evidence from this and other studies indicates that the presence of $[\mathrm{m}]$ is a recent development, occurring over the last $30-40$ years. In addition to the increase

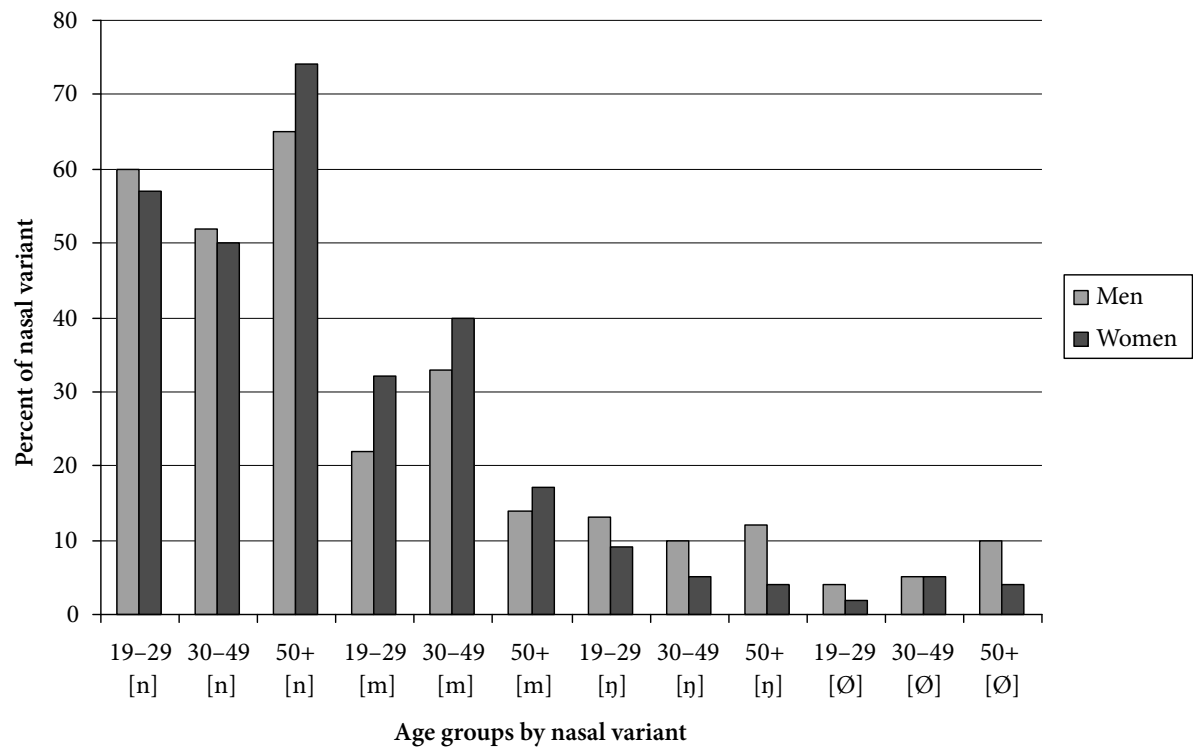

Figure 3. Cross tabulations of age and gender for all nasal variants 
for [m] in apparent time seen here, Yager (1989: 91) also showed an increase in [m] from older to younger speakers (see section 3). Allowing for the observed change in apparent time, the results from the present study most closely resemble those of Lope Blanch (1987: 42), who found that 73\% of final nasals surfaced as [n], $12 \%$ as $[\mathrm{m}], 8 \%$ as $[\mathrm{n}]$ and that $2 \%$ were deleted . Based on real time comparison of these two studies, realization of [n] has dropped $13 \%$, while $[\mathrm{m}]$ has increased a corresponding $13 \%$. The other two variants, $[\mathrm{n}]$ and $\emptyset$, have remained fairly constant. Additional support for the recent development of $[\mathrm{m}]$ is found in the fact that early studies of the dialect do not mention labial nasals at all, although they do detail other phonetic variations in YS, such as aspirated voiceless stops and glottalizations (see Barrera Vasquez 1937; Nykl 1938; Suarez 1945/1979).

Comparing the frequencies of $[\mathrm{m}]$ for middle age and younger speakers suggests a peak among age 30-49 speakers; although as noted previously the difference in rate of $[\mathrm{m}]$ for these two age groups was not found to be significant. Still, future real-time research is needed to determine if this trend is indicative of a reversal of what was a rapid change in the previous generation, or if the apparent difference in $[\mathrm{m}]$ frequency between middle aged and young speakers is due to the logarithmic peak seen in other studies of language change (see Labov 2001's discussion of Cedergren 1987).

Finally, as noted previously, the two remaining nasal variants, [n] and $\emptyset$ are infrequent, primarily male variants in competition with the standard variant [n], as well as the preferred female variant $[\mathrm{m}]$. Like $[\mathrm{m}],[\mathrm{n}]$ is favored by stressed syllables linguistically, and by higher class Mayan-speakers socially, but with a difference for gender, with men favoring [n] and women favoring [m] (see Tables 4, 5; 8, 9). Men produce twice as many tokens of [n] as do women (11\% vs. $5 \%)$. Among significant factors, higher class Mayan-speaking men show the highest rates of velarization (19\%). ${ }^{3}$ Deletion also arises more among men (6\% for men vs. $3 \%$ for women), but never reaches a frequency higher than $8 \%$.

\section{Final nasals and linguistic identity}

In reviewing the patterns for nasal variants in Merida, three important trends emerge. First, contra some previous reports, YS generally follows pan-Hispanic norms of nasal assimilation internally, and alveolar [n] finally. These cases account for $97 \%$ of all nasal variants. Also, in absolute final position, [n] still accounts for $60 \%$ of nasals. As a variety of Mexican Spanish, the general preference for standard [n] is not surprising, given the overall preference for the alveolar nasal in that country (see Canfield 1981; Lipski 1994). The significant preference for [n] among 
Spanish monolinguals from the higher social class (see Table 8) speaks to its status as the prestige variant for many in Yucatan.

Second, both velarization and nasal deletion are infrequent among speakers in Merida. Combined, they account for only $1 \%$ of non-neutralizing coda nasals, and in absolute final position [n] and ø occur at the relatively low rates of $8 \%$ and $5 \%$, respectively. In this way YS differs from neighboring Caribbean varieties. Interestingly, Canfield (1981) lists the Yucatan as a velarizing area of Mexico, although this observation conflicts with the apparent time frequencies from the present study, which seem to show velarization as a recent development, at least for these speakers in Merida.

Third, contra Alvar (1969: 168), bilabial [m] does not occur in the present corpus with "abrumadora frecuencia", accounting for only $2 \%$ of all coda nasals, although it does account for one fourth of absolute final nasals. Thus [m] is an important regional variant for some speakers, especially higher class Mayan-speaking women and middle age women who produced $52 \%$ and $40 \%[\mathrm{~m}]$ respectively.

An explanation of this trend in the Spanish of Merida must take into account both linguistic and extra-linguistic factors. From a phonetic standpoint, some research has shown labials to be more salient than coronals in both onset and coda position, likely due in part to the obvious gesture of lip closure during articulation (see Winters 2001). The phonetic salience of labial [m] may have played a role in the rapid adoption of a salient, regional variant among these women. As noted previously, the highest rates of [m] are found among middle aged women from poorer/ indigenous backgrounds (i.e. Mayan speakers) - these women currently hold middle or upper middle class jobs, ranging from secretary to lawyer, a substantial jump in social status compared to their Mayan-dominant parents or grandparents. As these women take advantage of increased educational opportunities and enter the middle/upper middle class (thereby losing their Mayan language), they adopt [m] with a frequency of $52 \%$ (vs. $34 \%$ for men in the same group). Thus for these speakers the national prestige variant, $[\mathrm{n}]$, is superseded by a regional variant $[\mathrm{m}]$ from a traditionally stigmatized variety (YS), while other regional pronunciations (stop [b d g], among others) have been shown to be recessing (Michnowicz 2006b). As noted by Tabouret-Keller (1997: 317), a single pronunciation may serve as a marker of in-group identity. Here, bilabial [m] may serve as a (semi-conscious) shibboleth of regional identity for some of these women in light of the increasing contact with speakers of other varieties of Spanish, particularly from Yucatan's traditional rivals in central Mexico, through the increased immigration, tourism and industry mentioned in section 2. Many speakers in the present study noted that traditional $y u$ cateco customs, such as food, holidays and speech are at risk of being overwhelmed by the new speakers of the prestigious dialect of Mexico City. Lipski (1994: 282283) demonstrates that this possibility is not without precedent, as other regional 
forms of language in different parts of Mexico, such as Veracruz and Acapulco, have been nearly eliminated in favor of Mexico City Spanish. Here, these speakers of Yucatan Spanish may be utilizing a salient regional variant, [m], as a way of preserving their status as native yucatecos in the face of these social changes, although further research is needed to confirm this hypothesis. Although some middle age speakers professed to not be aware of their high rate of $[\mathrm{m}]$ use, it is clear that some speakers relate the use of $[\mathrm{m}]$ to $y$ ucateco identity, as suggested by one website selling Yucatecan items that states "Se cambia la 'n' por una 'm' como es costumbre en Yucatám", thereby relating the production of $[\mathrm{m}]$ to regional mores. In this way developments in Yucatan may mirror trends observed in other Latin American regions, where young speakers are adopting previously stigmatized forms as signs of local solidarity (see Toribio 2000); for example, velar /r/ (Holmquist 2003, 2005) and glottal realizations of /s/ (Valentín-Márquez 2006) in Puerto Rico; the use of the pronoun vos in Chile (Torrejón 1986); and final vocalized liquids in Cibao, Dominican Republic (Pérez Guerra 1989; J. Lipski, personal communication).

While for some speakers the use of regional $[\mathrm{m}]$ appears to be related to a sense of local identity, for others the use of and attitude towards $[\mathrm{m}]$ may be changing. There is some evidence that $[\mathrm{m}]$ may be passing from a sociolinguistic indicator of regional identity to a linguistic stereotype of the dialect. A popular clothing store in Merida specializing in items with regional phrases sells t-shirts that emphasize the perceived Yucatan tendency toward [m], e.g. Vaya biem for vaya bien, or with the word camióm for camión". ${ }^{5}$ Likewise, the connection with [m] to local culture is seen through internet chat rooms and websites, where many users post statements that reflect at least a stereotypical knowledge of final [m], for example writing Yucatán as Yucatám. ${ }^{6}$ One such example is the website Real Academia de la Lengua de Yucatám, a personal weblog with the goal of showing "el uso real de la lengua en Mérida". The author of this weblog notes in the first posting that:

el pan es el pam y Yucatám es el lugar donde vivimos... si quiere pasar por yucateco mientras habla, elimine la $\underline{\mathbf{n}}$ y sustitúyala por la $\underline{\mathbf{m}}$ cuando esté al final de las palabras (emphasis in the original)

Here, the phonetic context for labialization is overstated (see the discussion of linguistic factors in section 5), and the use of [m] is connected to 'passing' for a native yucateco, suggesting that $[\mathrm{m}]$ is a salient feature of the dialect that would be easily imitable for speakers of other varieties. Some young speakers interviewed for this study indicate that the distinctive features of YS as a whole are taking on a stereotypical, albeit playful, connotation. Speaking about the dialect in general, one college student notes: 
Se da mucho entre jóvenes, grupos de amigos, entonces ya todo hasta a propósito lo hacen, o sea que te estás llevando con ellos y estás jugando o estás hablando o sea a propósito...marcas más tu acento.

Likewise, a young professional states that he and his friends use regional terms and pronunciations because "[nos] parece chistoso". Unlike most middle age speakers in this study, who profess ignorance of [m] even though they as a group demonstrative the highest frequencies of it, the existence of this regional variant is becoming more conscious among some younger speakers. The increased stereotyping of the regional variant $[\mathrm{m}]$ in the popular culture coupled with young speakers' attitudes toward YS may influence the future development of final nasals in the dialect, with one possibility being that $[\mathrm{m}]$ (and other dialect features) will be primarily relegated to jokes and imitations among younger speakers, rather than its current status as a locally prestigious, (semi-)conscious marker for middle aged, higher social group, Mayan-speaking women (see Wolfram \& Schilling-Estes 1995: 715; Schilling-Estes 1998 on the stereotyping and performance of the Ocracoke Brogue by some speakers of that variety who exaggerate the use of salient typical regional variants in order to appear more native). Importantly, this possibility would also result in the preservation of this regional dialect feature, albeit as a caricature of a previously valid social variant.

\section{Conclusions and areas for future research}

The present study has shown that final nasal choice in YS is sensitive to both linguistic and extra-linguistic factors. While $[\mathrm{n}]$ is the favored variant overall, women demonstrate increased frequencies of labial $[\mathrm{m}]$, while velar $[\mathrm{n}]$ and deletion are infrequent, but arise most often in male speech. Changes in apparent time suggest that the distribution of final nasals in YS is undergoing a shift, with increasing frequencies of $[\mathrm{m}]$ and to a lesser extent $[\mathrm{n}]$, among speakers under 50 . Increased contact with speakers of other varieties of Spanish, especially recent immigrants from central Mexico, is possibly an important factor in the adoption of non-standard variants, perhaps as a way for speakers to exert their regional identity. Results also demonstrate an effect for bilingualism on the production of [m], [n], and $\emptyset$, suggesting some role for the Mayan language via contact or L2 features in YS. This possibility is reserved for future study. Further research also should be undertaken to determine the final nasal preferences among children and young adolescents, as well as the perception speakers have of the regional variant $[\mathrm{m}]$ in order to determine this variant's future course. With regard to phonetic context, it remains to be discovered how much of a pause is needed to trigger the labial nasal, the determination of which may help explain some of the non-absolute final tokens of [m]. 
Finally, the overall salience of final nasal variants should be tested in Yucatan to determine a possible role for conscious adoption of different nasal variants by native speakers of Yucatan Spanish.

\section{Notes}

* I wish to thank John Lipski and Carol Klee for their insightful comments and generous help during the preparation of this article. Thanks also to Tonya Wolford for reading an earlier version of this manuscript, the anonymous reviewers and editors for their assistance, and to Robin Dodsworth for her invaluable statistics help. All errors, of course, remain mine.

1. A detailed phonetic analysis of nasal variants in Yucatan is reserved for future research.

2. Although Spanish does not normally allow a determiner or preposition in final position, examples do arise in this position in discourse as speakers pause in the middle of an utterance.

3. Although age was not selected as significant, young speakers belonging to the higher class Mayan-speaking group demonstrate the highest overall frequency of [n]: $23 \%$.

4. http://www.mayanxic.com/tendejon_detalles.php?p=9\&s=64, Retrieved March 17, 2008.

5. http://www.mayanxic.com

6. Numerous examples can be found with a quick web search of "Yucatám". A web search on Google by the author produced over 1,700 references (Retrieved March 24, 2008).

\section{References}

Alisky, Marvin. 1980. "The Relations of the State of Yucatán and the Federal Government of Mexico, 1823-1978". Yucatan: A World Apart ed. by Edward Mosely \& Edward Terry, 245263. University of Alabama: University of Alabama Press.

Alvar, Manuel. 1969. "Nuevas notas sobre el español de Yucatán”. Iberoromania I. 159-189.

Barrera Vásquez, Alfredo. 1937. "Mayismos y voces mayas en el español de Yucatán”. Investigaciones Lingüísticas 4. 9-35.

Biles, James J. 2004. "Export-oriented Industrialization and Regional Development: A Case Study of Maquiladora Production in Yucatán, Mexico". Regional Studies 38: 5. 519-534.

Bolles, David and Alejandra Bolles. 2001. A Grammar of the Yucatecan Mayan Language. Lancaster, California: Labryrinthos.

Canfield, D. Lincoln. 1981. Spanish Pronunciation in the Americas. Chicago: University of Chicago Press.

Cedergren, Henrietta. 1987. “The Spread of Language Change; Verifying Inferences of Linguistic Diffusion". Language spread and language policy: Issues, implications, and case studies 3:2. 45-60.

García Fajardo, Josefina. 1984. Fonética del español de Valladolid, Yucatán. Mexico City: Universidad nacional autónoma de México. 
Gordon, Raymond G., Jr. (ed.). 2005. Ethnologue: Languages of the World (15th edition). Dallas, Texas: SIL International. Available from: http://www.ethnologue.com. Accessed 16 March 2008.

Hualde, José Ignacio. 2005. The Sounds of Spanish. Cambridge University Press.

Hume, Elizabeth. 2003. "Language specific markedness: The case of place of articulation". Studies in Phonetics, Phonology and Morphology 9:2. 295-310.

Hume, Elizabeth and Georgios Tserdandelis. 2002. "Labial Unmarkedness in Sri Lankan Portuguese Creole". Phonology, 19: 3. 441-458.

Instituto nacional de estadística, geografía e informática (INEGI). 2000. XII Censo general de población y vivienda [electronic version]. Aguascalientes, Mexico. Available from: http:// www.inegi.gob.mx.

Instituto nacional de estadística, geografía e informática (INEGI). 2005. Conteo de población $y$ vivienda 2005 [electronic version]. Aguascalientes, Mexico. Available from http://www. inegi.gob.mx.

Joseph, Gilbert M. 1980. "Revolution from without: The Mexican Revolution in Yucatán, 19101940”. Yucatan: A World Apart ed. by Edward Mosely \& Edward Terry, 142-171. University of Alabama: University of Alabama Press.

Kent, Raymond D. and Charles Read. 1992. The Acoustic Analysis of Speech. San Diego, California: Singular.

Labov, William. 2001. Principles of Linguistic Change: Social Factors (vol. 2). Oxford: Blackwell.

Labov, William.1984. Field Methods of the Project on Linguistic Change and Variation. Language in Use: Readings in Sociolinguistics ed. by John Baugh \& Joel Sherzer, 28-53. Englewood Cliffs, NJ: Prentice-Hall.

Labov, William. 1966. The Social Stratification of English in New York City. Washington, DC: Center for Applied Linguistics.

Lipski, John M. 1994. Latin American Spanish. New York: Longman.

Lipski, John M. June 7, 2007. Personal communication.

Lope Blanch, Juan M. 1987. Estudios sobre el español de Yucatán. Mexico City: Universidad Autónoma de México.

Mayan Xic. Available from http://www.mayanxic.com. Accessed 1 March 2008.

Mediz Bolio, Antonio. 1951. Interinfluencia del maya con el español de Yucatán. Merida, Mexico: Editorial Zamná.

Michnowicz, Jim. In Press. "Intervocalic voiced stops in Yucatan Spanish: A case of contactinduced language change?" Español en Estados Unidos y en otros contextos: Cuestiones sociolingüísticas, políticas y pedagógicas ed. by Manuel Lacorte \& Jennifer Leeman, Madrid: Iberoamericana.

Michnowicz, Jim. 2006a. "Final -m in Yucatan Spanish: A Rapid and Anonymous Survey". New Perspectives on Romance Linguistics, vol. 2. Phonetics, phonology, and dialectology: Selected papers from the 35th Linguistic Symposium on Romance Languages (LSRL) ed. by Jean-Pierre Montreuil, 155-166. Amsterdam: John Benjamins.

Michnowicz, James Casimir. 2006b. Linguistic and Social Variables in Yucatan Spanish. Doctoral dissertation, Penn State University: University Park, Pennsylvania.

Mosely, Edward H. 1980. "From Conquest to Independence: Yucatan under Spanish Rule, 15211821”. Yucatan: A World Apart ed. by Edward Mosely \& Edward Terry, 83-121. University of Alabama: University of Alabama Press. 
Nykl, Aloys R. 1938. "Notas sobre el español de Yucatán Veracruz y Tlaxcala”. El español en Méjico, Los Estados Unidos y la América Central ed. by Pedro Henríquez Ureña, 207-225. Buenos Aires, Argentina: La Universidad de Buenos Aires.

Pérez Guerra, Irene. 1989. "Un caso de prestigio encubierto en el español dominicano: La 'vocalización cibaeña”. Actas del III Congreso Internacional de el Español en América, vol. 3. Valladolid, Junta de Castilla y León, 1185-1192.

Pfeiler, Barbara.1992. Así som, los de Yucatán: El proceso fonológico $\mathrm{Vn}>\mathrm{m} /$ __ $_{\text {(\#, C) en dos }}$ lenguas en contacto. Memorias del Primer Congreso Internacional de Mayistas, vol. 1, 110122. San Cristóbal de las Casas, Mexico.

Quezada, Sergio. 2001. Breve historia de Yucatán. Mexico City: El Colegio de México.

Real Academia de la República de Yucatám. Available from http://yucatam.blogspot.com. Accessed 1 June 2007.

Romero Castillo, Moisés. 1963. "Los fonemas del maya-yucateco". Anales del Instituto Nacional de Antropología e Historia. XVI, 179-192. Mexico City: Mexico.

Suarez, Victor M. 1945/1979. El español que se habla en Yucatán: Apuntamientos filológicos (2nd edition). Merida, Mexico: La universidad de Yucatán.

Tabouret-Keller, Andrée. 1997. "Language and identity". The Handbook of Sociolinguistics ed. by Florian Coulmas, 313-326. Oxford, UK: Blackwell.

Teschner, Richard V. 2000. Camino oral: fonética, fonología y práctica de los sonidos del español. New York: McGraw-Hill.

Thomason, Sarah G. 2001. Language Contact: An introduction. Washington, DC: Georgetown University Press.

Toribio, Almeida Jacqueline. 2000. "Nosotros somos dominicanos: Language and self-definition among Dominicans". Research on Spanish in the United States: Linguistic Issues and Challenges ed. by Ana Roca, 252-270. Somerville, Massachusetts: Cascadilla Proceedings Project.

Valentín-Márquez, Wilfredo. 2006. "La occlusion glottal y la construcción linguística de identidades sociales en Puerto Rico". Selected Proceedings of the 9th Hispanic Linguistics Symposium ed. by Nuria Sagarra and Almedia Jacqueline Toribio, 326-341. Somerville, Massachusetts: Cascadilla Proceedings Project.

Weber, Irving L. 1980. "Social Organization and Change in Modern Yucatan”. Yucatan: A World Apart ed. by Edward Mosely and Edward Terry, 172-201. University of Alabama: University of Alabama Press.

Winters, Stephen. 2001. "VCCV Perception: Putting place in its place". Ohio State Working Papers in Linguistics ed. by Keith Johnson and Elizabeth Hume, 55, 70-81.

Winters, Stephen. 2000. “Turning phonology inside out, or Testing the relative salience of visual cues for place of articulation". Ohio State University Working Papers in Linguistics ed. by Amanda Miller-Ockhuizen, Robert Levine, and Anthony J. Gonsalves, vol. 53, 168-199.

Wolfram, Walt and Natalie Schilling-Estes. 1995. "Moribund dialects and the endangerment canon: The case of the Ocracoke Brogue”. Language 71:4. 696-721.

Yager, Kent. 1982. Estudio del cuadro consonántico del español de Mérida, Yucatán con consideraciones de posible influencia maya. Unpublished master's thesis, University of California: Santa Barbara.

Yager, Kent. 1989. "La -m bilabial en posición final absoluta en el español hablado en Mérida, Yucatán (México)”. Nueva Revista de Filología Hispánica, XXXVII (I). 83-94. 
